\title{
Digital competences in the aspect of sociocultural education
}

\author{
Madina Zhardemova ${ }^{1 *}$, Tatyana Khristidis $^{1}$, Natalya Karmazina $^{2}$, Svetlana Fedorova ${ }^{3}$, and \\ Ekaterina Yakovleva ${ }^{4}$ \\ ${ }^{1}$ Moscow State University of Culture, Department of Pedagogy and Psychology, Moscow, Russia \\ ${ }^{2}$ Ministry of Education of the Republic of Karelia, Petrozavodsk, Republic of Karelia, Russia \\ ${ }^{3}$ Ulyanovsk State Agrarian University named after P.A. Stolypin, Ulyanovsk, Russia \\ ${ }^{4}$ Petrozavodsk State University, Institute of Foreign Languages, Department of German, \\ Petrozavodsk, Russia
}

\begin{abstract}
The purpose of this paper is to examine different social and academic activities related to the development of a digital culture of bachelors and masters of culture and arts. It analyses the achieved results of the research project aimed at the study of educational and pedagogical opportunities and resources for the more effective development of digital competencies of students and graduates in the life-long system of sociocultural education and realized in the Moscow State University of Culture (Khimki, Moscow region), the Petrozavodsk State University (Petrozavods, Republic of Karelia) and in the Ulyanovsk State Agrarian University named after P.A. Stolypin (Ulyanovsk) in 2010-2019. The authors consider digital competences as a core of a digital culture of graduated in arts and culture is a multi-level, complex, interdisciplinary phenomenon, and therefore it needs a comprehensive analysis from the standpoint of several sciences (philosophy, sociology, psychology and pedagogy, etc.). The results of the implementation of educational technologies orientated to values and competences of a digital culture are discussed. The paper focuses on the importance of the educational process orientated on creation of values of digital culture which are significant for the organization of social and cultural activities in the frame of the state policy on digitalization of education and culture.
\end{abstract}

Keywords: digitalization, sociocultural education, digital competence, digital culture.

\section{Introduction}

The study of digital professional competencies of bachelors and masters of arts and culture is one of the most actual problems of the methodology, theory and technologies of higher sociocultural education $[1,2]$. It was John Adams, a famous American statesman, who said, that "there are two educations. One should teach us how to make a living and the other how to live" [3].

\footnotetext{
*Corresponding author: mmukanova@mail.ru
} 


\subsection{Problem statement}

The present-day mission of universities and colleges of arts and cultures is to educate and to prepare a competent and competitive graduate, fluent, creative and mobile in his profession, able for successfully adaptation to the changing society and cultures, capable to effective social and cultural activities and to professional life-long education and self-development [4].

On the other hand, in the wider aspect of the problem, the modern labor market requires the availability of labor resources that have a high degree of social and professional mobility and a digital culture to live and to work in the changing post-industrious digital society [5, p. 6-8].

The practical solution of the problem of digital culture development requires a deep theoretical reflection of the nature of this phenomenon to understand the mechanisms of its implementation as well as the very conditions and factors that cause them. Digital competences as a core of a digital culture of graduated in arts and culture is a multi-level, complex, interdisciplinary phenomenon, and therefore it needs a comprehensive analysis from the standpoint of several sciences (philosophy, sociology, psychology and pedagogy, etc.) $[6,7]$. The same refers to the problem of graduates' digital culture that can be defined as the synthesis of specific values, meanings, competencies and individual ways of professional self-representation and practices in social and cultural activities in the conditions of digitalization.

The theoretical analysis has led us to the conclusion that different aspects of the phenomenon of digital competences have been successfully studied for the last decade [8, 9]. Nowadays it is presented in different concepts of philosophers, sociologists, anthropologists, psychologists and pedagogues.

The theoretical foundations of the digital educational process based on innovative technologies in the modern information and educational environment are being developed also both in the Russian Federation [10] (A. Akhayan, E. Klochkova, T. Khristidis, A. Kondakov, I. Remorenko, I. Robert, N. Sadovnikova, A. Semyonov, A. Tryapitsyna, etc.) and in the other countries [11-13] (E. Ahmeti, A. Bertram, K. Brundier, O. Erstad, J. Hermna, S. Raizen, M. Ripley, A. Wiek, etc.).

\subsection{Research questions. Purpose of the study}

Our research project was aimed at the analysis of educational and pedagogical opportunities and resources for the more effective development of digital competencies of students and graduates in the life-long system of sociocultural education.

The hypothesis of the research was formulated as follows: we proceeded from the understanding the phenomenon of digital competences of students and graduates of universities and colleges of arts and culture as an integrative professional and individual quality of a person that can be purposefully and successfully developed in the educational process, if it:

a) is implemented on the basis of so call "interactive developmental educational and pedagogical technologies" (including regular debates with the students and teachers form the partner-universities via Internet, internet brainstorming, internet co-working, etc.) and the technology of the electronic portfolio, as well as multimedia courses, electronic textbooks, web pages on the Internet, social media, etc.

b) ensures the effective involvement of students in various educational activities with the opportunities provided by the digital educational environment (Internet, social media and digital educational resources, including methods of designing their own professional career, project activity, etc.); 
c) is focused on ideas of "a dialogue of cultures", professional and cultural selfdevelopment and on-going education in the intercultural digital society and education.

\section{Methods}

A set of methods adequate to the goals and objectives was used in the study.

The research project was realized in the Moscow State University of Culture (Khimki, Moscow region), the Petrozavodsk State University (Petrozavods, Republic of Karelia) and in the Ulyanovsk State Agrarian University named after P.A. Stolypin (Ulyanovsk) in 2010-2019.

\section{Results and discussion}

Modern concepts of socio-cultural education in the Russian Federation pay special attention to the social and professional importance of development socio-professional mobility and a digital culture among pedagogical students in the system of long-life teacher training [1418] (A. Akhayan, E. Klochkova, T. Khristidis, A. Kondakov, S. Karakozov, I. Remorenko, I. Robert, N. Sadovnikova, A. Semyonov, A. Tryapitsyna, etc.).

Currently, Russia is actively implementing the presidential initiative to digitalize the economy. The main strategies of digitalization are formulated in the Federal State Program "Digital Economy of the Russian Federation". The Presidium of the Presidential Council for strategic development and priority projects approved the priority national project on digitalization of education in the Russian Federation for the period of 2018-2024 as a part of the Federal Program "The Digital Economy of the Russian Federation”. The Ministry of Education of Russian Federation together with educational institutions and communities of teachers, parents and schoolchildren realizes the target federal program on creation digital educational infrastructure of a new generation.

It is a paradox, but the 2019-2020 pandemic of coronavirus influenced greatly and very positively on the intensive development of the digital cultural environment in Russia. According to the Microsoft, at present more than $85 \%$ of the surveyed museums in Moscow, the Moscow region, St. Petersburg and the Leningrad region recognize the need for digital transformation. In particular, $20 \%$ of respondents have been actively implementing a digitalization strategy, $23 \%$ have developed it, and $43 \%$ are planning to do so. The main priority in this direction was to create digital opportunities for visitors - this was noted by $82 \%$ of respondents. According to experts, the focus is on interactive interaction with clients not only during exhibition visits, but also through online formats. For this purpose, the sphere of art and culture actively uses modern technologies and attracts specialists from this field.

According to the official information of the Ministry of Culture of the Russian Federation and the results of the special study organized by experts, nowadays quite a lot of attention is paid to interacting with people through innovation: more than $50 \%$ of respondents already use or implement virtual/augmented reality technologies, $33 \%$ use audio guides, about a quarter use virtual assistants (24\%) and Museum navigation (23\%). As a tool for digitizing Museum processes, the majority of respondents already use artificial intelligence technologies or plan to start doing so (53\%). In 2020, more than a third of respondents are also starting to implement VR/AR to solve various tasks, and almost the same number are planning to turn to multimedia solutions (33\%). Cloud technologies are widely used: $26 \%$ of organizations solve their tasks using a public cloud, and $22 \%$ prefer hybrid scenarios. In addition, modern museums actively interact with the audience remotely - for example, more than $80 \%$ of respondents give the opportunity to purchase tickets 
online, $44 \%$ use a virtual guide, $37 \%$ of respondents support a loyalty program, and $34 \%$ have an online store where visitors can buy souvenirs, catalogs, books, and additional services. In addition, museums are actively present in social networks, conduct email newsletters, and regularly research their audience. The same can be said about theatres and libraries.

It is quite natural, that specialist in sociocultural activity should know how to create the digital environment of cultural life due to the present-day social and cultural challenges, and this is a special responsibility for universities and colleges of arts and culture.

The Federal State Educational Standard of High Education (the levels of baccalaureate and master's degree levels) includes both competencies of social and professional mobility and competences in digital education.

The experimental teaching and learning within the research project were realized in the Moscow State Institute of Culture, the Petrozavodsk State University (Institute of Foreign Languages) and in the Ulyanovsk State Agricultural University. The technology of the electronic portfolio was widely used in the educational process. An electronic portfolio has much more advantages than a traditional printed version as it contains of a large amount of materials, is characterized by interactivity, providing rapid access, including remote, stimulates the ability to collect, edit and demonstrate the results in a visual form through the use of various formats - text, audio, graphic, video, etc. The offered system of hyperlinks and hypertext allows students to make their own design of the electronic portfolio. We made a conclusion that IC-technologies transform competences (both social, cultural and professional) and develop students' critical thinking. The electronic portfolio (computer literacy + information mobility + reflection) stimulates students' professional growth and development of professional culture.

The principles of professionally orientated teaching and learning allowed us to propose a number of methodological requirements to develop a digital competences significant for the professional social and cultural activities of bachelors and masters. All methods used in the educational process should introduce and assimilate students in a digital culture, to create students' cultural individuality on different levels. The methods used in the educational process should be professionally oriented, that stimulates the process of development of digital skills and competences. A set of communicative exercises should have an intercultural and interactive orientation, which contributes to the intellectualization and intensification of the educational process.

The final results showed, that $35 \%$ of the total number of participants of the experiment (65 students) achieved a high level of digital culture, $45 \%$ of students ( 84 respondents) were on the average level, and only $10 \%$ of students remained at a low level (19 students).

\section{Conclusion}

The results of the experimental work confirmed the positive effect of the proposed set of educational and pedagogical conditions and tools that contribute to the development of digital competences among bachelors and masters specialized at sociocultural activity education. In general, on the basis of the study, new theoretical and practical knowledge of digital competences of students have been obtained. 


\section{References}

1. The Agency of Strategic Initiatives, Atlas of New Professions 2030 (The "Skolkovo" Innovation Center, Moscow, 2015). Accessed on: December 16, 2020. [Online]. Available: http://atlas100.ru/about/

2. FOMNibus, Internet and education. Do Russians use the Internet for educational purposes? (2015). Accessed on: December 16, 2020. [Online]. Available: http://fom.ru/Nauka-i-obrazovanie/12256

3. P.A. Sorokin, Social and cultural mobility (Free Press, New York, 1959)

4. J.M. Farrell, J. Adams, The New England Quarterly 62.4, 505-528 (1989)

5. A.V. Keshelava, V.G. Budanov, V.Y. Rumyantsev, Vvedenie v "tsifrovuyu" ekonomiku (VNII Geosistem, Moscow, 2017)

6. S. Baller, S. Dutta, B. Lanvin, (Eds.), The Global Information Technology Report 2016. Innovating the Digital Economy. Insight Report (World Economic Forum, Geneva, 2016). Accessed on: December 16, 2020. [Online]. Available: http://www3.weforum.org/docs/GITR2016/WEF_GITR_Full_Report.pdf

7. K. Brundiers, A. Wiek, Education Sciences, 7(1), 39 (2017). https://doi.org/10.3390/educsci7010039.

8. H.B. Taskiran, Digitalization of Culture and Art Communication: A Study on Digital Databases and Digital Publics, in Handbook of Research on Examining Cultural Policies Through Digital Communication, 144-160 (2019). https://doi.org/10.4018/978-1-5225-6998-5.ch007

9. E. Ahmeti, Australian Journal of Humanities and Social Studies, 11-12 (2015)

10. V.V. Laptev, Metodologiya vizualizatsii (Mir, Moskva, 2018)

11. D. Newman, Top 6 Digital Transformation Trends in Education (2017), Retrieved from: https://www.forbes.com/sites/danielnewman/2017/07/18/top-6-digitaltransformation-trends-in-education/\#12cf69812a9a

12. T. Barkatsas, A. Bertram, (Eds.), Global learning in the 21 st century. (Sense Publishers, Boston, MA, 2016)

13. M. Binkley et al., Defining 21st century skills, in Assessment and Teaching of 21st Century Skills, 17-66 (Springer, Dordrecht, 2012)

14. V.V. Eremin, E.V. Kharisova, Shkola-internat dlya odarennykh detey MGU - obrazets obucheniya $v$ menyayushchemsya mire [MSU boarding school for gifted children is a model of learning in a changing world], in Yestestvennonauchnoye obrazovaniye: vzglyad v budushcheye, 240-245 (Moscow State University Publishing, Moscow, 2016)

15. M. Grenfell, The European Profile for Language Teacher Education (2005). Accessed on: December 16, 2020. [Online]. Available: http://www.leeds.ac.uk/educol/documents/149908.htm\#: :text=The\%20European $\% 20$ Profile\%20for\%20Language $\% 20$ Teacher\%20Education $\% 20 \%$ EF\%BF\%BD\%20A\%20 Frame,Strategies $\% 20$ and $\% 20$ Skills $\% 2 \mathrm{C} \% 20$ and $\% 20$ Values

16. S. Palyohina, The role of the European language portfolio in the development of social and professional mobility of the future foreign language teacher, in Sovremennye tekhnologii v rossijskoj sisteme obrazovaniya. Conference proceedings of VII Allrussian scientific and practical conference, May 2009, Penza, Russia (2009).

17. S. Palyohina, Vestnik Kostromskogo gosudarstvennogo universiteta imeni N.A. Nekrasova. Seriya "Pedagogika. Psihologiya. Social'naya rabota", 15, 54-57 (2009) 
18. Z.G. Proshina, A.A. Eddy (Eds.), Russian English: History, Functions, and Features (Cambridge University Press, Cambridge, 2016) 